\title{
Study of Staphylococcus aureus isolated from the mouth of canary
}

\author{
S.A. Hussein \\ Department of Microbiology, College of Veterinary Medicine, University of Mosul, Mosul, Iraq \\ Email: sabaabdulraheem9@gmail.com
}

(Received July 21, 2019; Accepted August 30, 2019; Available online June 11, 2020)

\begin{abstract}
The study was done for described genotypically characterize of Staph. aureus isolated from the oral cavity of canary birds in Mosul city using polymerase chain reaction technique which was achieved by amplifying of the thermonuclear nuc gene specialized with Staph. aureus. Sixty birds were examined from variable ages of both sexes from different regions of Mosul city for the period of 1/5/2018-1/6/2019 was carried out. The results indicate that 35 samples gave Staph. aureus with the percentage of $58.4 \%$. These isolates are positive for pigmentation of mannitol salt agar, hemolysis on blood agar, catalase and coagulasepositive, gram staining and oxidase negative. PCR technique indicate that all 35 isolates were positive for the nuc gene and produce amplicon of $166 \mathrm{bp}$. These results considered positive and it is very specific for bacterial isolates of staph aureus as well as may be used for strain isolation, characterization, and differentiation from other types of bacteria.
\end{abstract}

Keywords: Cultural methods, PCR, Pet birds

DOI: 10.33899/ijvs.2019.125937.1192, () 2020, College of Veterinary Medicine, University of Mosul. This is an open access article under the CC BY 4.0 license (http://creativecommons.org/licenses/by/4.0/).

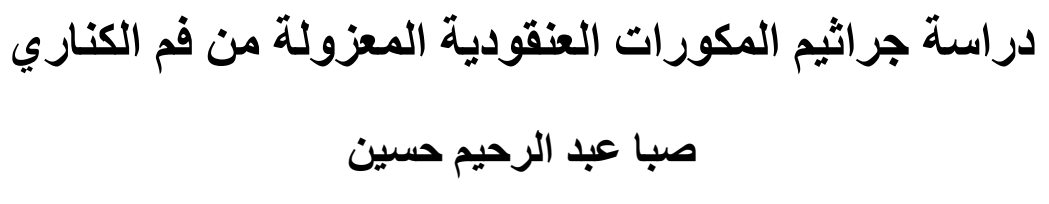

فرع الأحباء المجهرية، كلية الطب البيطري، جامعة الموصل، الموصل، العراق

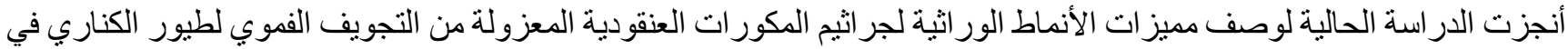

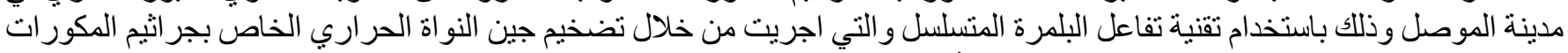

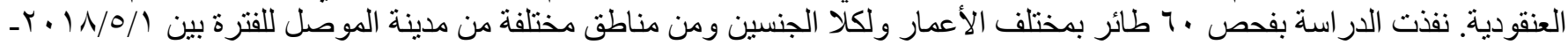

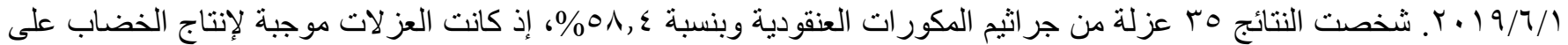

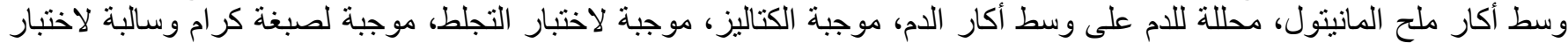

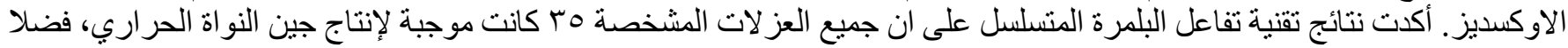

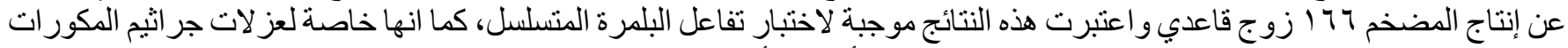

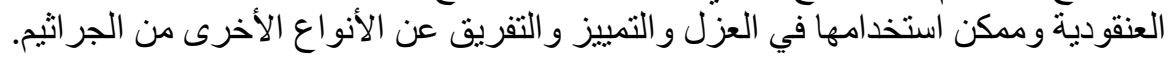

\section{Introduction}

Canaries was first bred in captivity in $17^{\text {th }}$ century, then brought by sailor, became expensive and fashionable to breed, also breeding by rich only, thus made them very popular $(1,2)$. In canary's disease, the diagnostic character was that the bird was very good at hiding their illness from owner; this is a part of hereditary trait, until reach the last stage of disease (3). Previously Staphylococcal infection in canary was only described in general terms of bird diseases books, but present studies thought that Staph. aureus could cause death in canaries kept in aviaries (4). Staphylococcal 
food- borne infections resulting from ingestion of contaminated food with bacterial toxins of Staph. aureus is a great cause of food-borne disease $(5,6)$. Gonzales (7) showed that Staphylococcus is very serious infected disease in canary. Staphylococcal infection in bird was differ according to the site and route of infection also when enter the blood stream cause systemic infection in many organs leading to breakdown and finally sever economic losses (8). The most common infection includes those that affect the sinuses or upper respiratory tract, intestinal tract and liver, urinary and reproductive tract, and the skin including feather follicles. Polymerase chain reaction (PCR) is a rapid method for determination of Staph. aureus. Hence, it is considering the method of choice, in comparison with other method, which are time consuming, susceptible to contamination due to manual method and unsuitable for routine diagnostic laboratories (9).

The aim of this work is to describe genotypically characterize of Staph. aureus isolated from oral cavity of canary birds in Mosul city using PCR technique.

\section{Material and methods}

\section{Bacterial isolation and identification}

Sixty swabs were taken from oral cavity of canary bird of both sex and different ages. The sample collected from bird shops in Mosul city. The swab was transported immediately to laboratory of Microbiology, College of Veterinary Medicine, University of Mosul. Under sterile condition, cotton swabs were placed in nutrient broth for 24 hours at $37^{\circ} \mathrm{C}$, A loopful from incubated broth were cultured on blood agar, milk agar and mannitol salt agar and incubated at $37^{\circ} \mathrm{C}$ for 24 hours, pure single colony were examined for gram staining, morphological and biochemical tests (10-12).

\section{DNA extraction}

Isolates were cultured on blood agar for $24 \mathrm{hrs}$ at $37^{\circ} \mathrm{C}$. DNA extraction were carried out according to the manufactured company (Geneaid, Biotech Ltd., Registration No QAIC/TW/50077, Korea). The colonies were suspended in $200 \mu \mathrm{l}$ of $\mathrm{RBC}$ lysis in water both at $60^{\circ} \mathrm{C}$ overnight, Vortex 1-2 min, added $200 \mu \mathrm{l}$ of FABG buffer, vortex 1-2 min, added $200 \mu 1$ of ethanol in column and filter centrifuge $14000 \mathrm{rpm}$ at $1 \mathrm{~min}$, added $400 \mu \mathrm{l}$ of wash buffer 1 , centrifuge $14000 \mathrm{rpm}$ at $1 \mathrm{~min}$, added $600 \mu \mathrm{l}$ of wash buffer 2, centrifuge $14000 \mathrm{rpm}$ at $1 \mathrm{~min}$, drying the sample by centrifugation, finally added $100 \mu \mathrm{l}$ of Elution

buffer, centrifuged for $5 \mathrm{~min}$, the bacterial DNA obtained from isolates was found in supernatant which was placed into a new tube and keep under freezing until used as DNA template $(9,13)$.

\section{PCR Detection of Staph. aureus}

For PCR amplification, the mixture $20 \mu 1$ which consist of $10 \mu \mathrm{l}$ Master Mix, $2 \mu 1 \mathrm{MgcL}_{2}, 2 \mu 1$ of primer 1 (nис 1), 2 $\mu \mathrm{l}$, of primer 2 (nис 2), and $4 \mu \mathrm{l}$ of distilled water. Primers was shown in table 1 (14).

Table 1: Primers used in study

\begin{tabular}{lll}
\hline primer & \multicolumn{1}{c}{ Nucleotides } \\
\hline \multirow{2}{*}{$n u c-1$} & 5-CCTGAAGCAAGTGCATTTACGA- & \\
& \multicolumn{1}{c}{166} \\
$n u c-2$ & 5- & \\
& CTTTAGCCAAGCCTTGACGAACT-3 & \\
\hline
\end{tabular}

This mixture was added to $4 \mu \mathrm{l}$ of prepared DNA. The tube placed in to thermal cycling (15), with programmer of 90 minutes (denaturation at $95^{\circ} \mathrm{C}, 30$ second; annealing at 50 ${ }^{\circ} \mathrm{C}, 30$ second; extension at $72^{\circ} \mathrm{C}, 30$ second and final extension at $72^{\circ} \mathrm{C}, 5$ minutes) (16). Electrophoresis were determined by adding the mixture, which consist of $10 \mu \mathrm{l}$ of prepared DNA and $2 \mu$ of loading buffer. This mixture added to $2 \%$ an agarose gel containing ethidium bromide along with $3 \mu \mathrm{l}$ of standard molecular marker (Biozym Diagnostic) (17). Finally, we saw the band under UV transilluminator $(18,19)$. All equipment, which was used in present study, belong to one system (Biometry, RudolfWisselt - Str. 30, 3707g Gottingen, Germany).

\section{Result}

Our study indicates that, Staphylococcus aureus was identified as positive for pigmentation on mannitol salt agar, hemolysis on blood agar, catalase and coagulase positive, oxidase negative, and positive for gram staining. From the total of 60 swabs we were found that only 35 isolates were Staph. aureus $58.4 \%$. The result of RCR revealed that the amplification of thermonuclear $n u c$ gene and produce an amplicon of $166 \mathrm{bp}$, which is expected PCR product size in the isolates of Staph. aureus. Amplicon of nuc gene are shown in figure 1.

\section{Discussion}

Staphylococci spp.cause varies infections in farm workers and broilers (22), so the ratio of bacterial isolation of our study are nearly compatible to that of reported (23) who recorded that $53.33 \%$ from oral swabs of caged parrots, and faraway from data recorded (24) from the oral swabs of water birds $37.5 \%$. The difference in percentage of isolation indicate the unhygienic breeding of bird and opportunistic behavior of Staph. aureus (25), in addition the bacteria owns many virulence factors which contribute the bacterial adhesion, invasion and colonization in bird (26-29). Others factors, including cellular immunity inhibition and condition 
of nutrition (30). Production of amplicon of $166 \mathrm{bp}$, which consider a positive isolate, this reflects the suggestion of a great role of this element in the pathogenicity of Staph. aureus in canary.

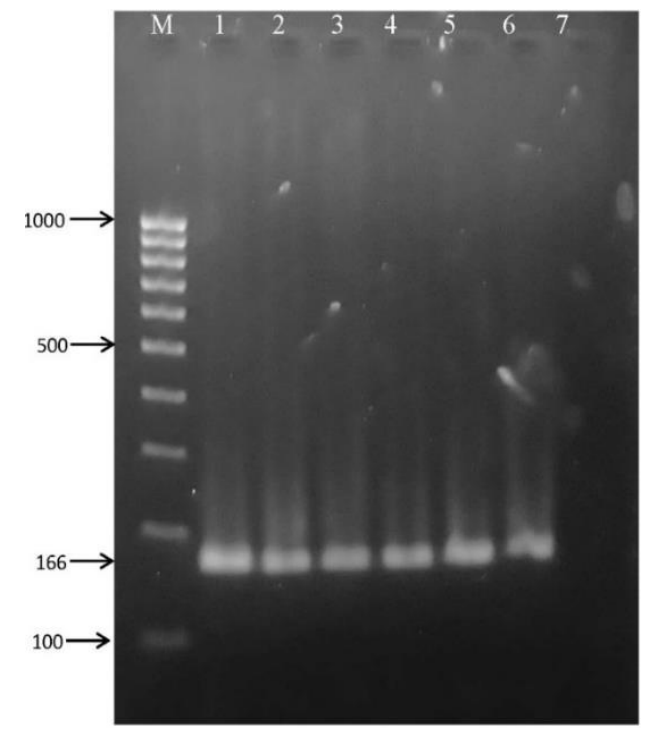

Figure 1: Agarose gel electrophoresis (2\%) showing the typical amplicon of the nuc gene product of Staph. aureus isolates. The amplification of DNA appears as a ladder-like pattern. Lane 1 is the positive control, Lanes 2-6 represent positive isolates, and Lane 7 is a non-template control. Lanes $\mathrm{M}$ are DNA Marker 100 bp ladder (Biozym Diagnostic).

At present, the information is little about use of PCR technique for detection of Staph. aureus isolated from canary bird origin, so a comparable study for PCR Identified of Staph. aureus from bird had been determined in (6) who recorded various virulence determinant of Staph. aureus in captive birds. Genotypically, others (31) who isolated Staph. aureus from lame birds and used Random amplification of polymorphic DNA.

We wanted to be achieved a new study for identified of Staph. aureus genotypically in canary bird because it is very necessary to show the properties of strains in order to look more detailed about epidemiological spreading of genetic patterns which is an effect on animal and human health (32).

\section{Conclusion}

The results of our study may help pet bird clinicians to interpret the microbiological culture and PCR results especially in canary bird, so the use of molecular methods for detection of Staphylococcal diseases in canary was very little or rare, thus we need further studies to know the sequencing of DNA and to detect the virulence determinant of Staph. aureus in canary bird by using PCR technique to prevent the spreading of pathogenic strain of bacteria between birds.

\section{Acknowledgments}

The author would like to thank the dean of the College of Veterinary Medicine, the head of Department of Microbiology, the PCR unit in the College of Veterinary Medicine, University of Mosul, as well as Dr. Omar Hashim Sheet and Dr. Zahraa Al-Mustafa for their excellent technical assistance.

\section{Conflict of interest}

The author declares that there are no conflicts of interest regarding the publication of this manuscript.

\section{References}

1. Arnaize VA, Ruiz VV, Areces C. El origen de los canarios. Ornithologia Prac. .2012;53:3-11. Available at http://www.chopo.pntic.mec/biolomol

2. Eschener K. The story of real canary in the coal mine. Smithsonian. 2016. Available at http://www.smithsoniamag.com

3. Babazadeh D, Ghavami S, Nikpiran H, Dorestan N. A cute megabacteriosis and statphylococosis of canary in iran. J World Poult Res. 2015;5(1):19-20.

4. Devriese LA, Herdt de P, Desmidt M, Dom P, Ducatelle R, Godard C, Haesebrouck F, Uyttebroek E. Pathogenic staphylococci and staphylococcal infection in canaries. Avai Pathol. 1994;23(1):159-162. 10.1080/03079459408418983

5. El-Sayed A, Alber J, Bonner B, Huhn A, Kaleta EF, Zschock M. PCRbased detection of genes encoding virulance determinant in Staphylococcus aureus from birds. J Vet Med B. 2005;52:38-44. 10.1111/j.1439-0450.2004.00814.x

6. Hamad MA, Hussein SA, Mahmmoud EN, ALAalim AM. The inhibitory role of effective microorganisms on the growth of pathogenic bacteria. Iraqi J Vet Sci. 2020;34(1):153-158. 10.33899/ijvs.2019.125653.1123

7. Gonzalez H. Diagnostic challenge. J Exotic Pet Med.2007;6(4):270277. 10.1053/J.Jepm.7007.12.011

8. Onaolapo JA, Igwe JC, Bolaji RO, Adeshina GO, Parom SK. Antibiotics susceptibility profile of Staphylococcus aureus isolated from poultry birds in Kaduna, Nigeria. J Clin Microboil Antimicrob. 2017;1:1-6.

9. Klaschik S, Lehmann LE, Steinhagen F, Book M, Molitor E, Hoeft A, Stueber F. Differentiation between Staphylococcus aureus and coagulase- negative staphylococcus species by real-time PCR including detection of methicillin resistants in comparison to conventional microbiology testing. J Clin Lab Analysis. 2015;29(2):122-128. 10.1002/jcla.21739

10. Cruiskshank RC, Dugnid J P, Marmion B P, Swain RH. Medical microbiology.12 $2^{\text {th }}$ ed. London: Churchill Livingstone; 1975. 77 p.

11. Tille PM. Diagnostic microbiology. $13^{\text {th }}$ ed. Oxford: Oxford University Press; 2014. 1309/LM5JC0PH0OGGBSZZ

12. Procop GW, Church DL, Hall GS, Janda WM, Koneman EW. Koneman's color atlas \& textbook of diagnostic microbiology. $7^{\text {th }}$ ed. Philadelphia: Wolters Kluwer Health; 2017. 63-80 p.

13. Wilson K. Preparation of genomic DNA from bacteria. Curr Prot Molr Biol. 2001;56(1):1-5. 10.1002/0471142727.mb0204s56

14. Graber HU, Casey MG, Naskova J, Steiner A, Schaeren W. Development of highly sensitive and specific assay to detect 
staphylococcus aureus in bovine mastitis milk. J Dairy Sci. 2007;90:4661-4669. 10.3168/jds.2006-902

15. Masny A, Plucienniczak A. Ligation mediated PCR performed at low denaturation temperature- PCR melting profiles. Nucleic Acid Res. 2003;31(18):114-114e. 10.1093/nar/gng116

16. Nashev D, Toshkova K, Salasia SI, Hassan AA, Lamer C, Zschock M, Distribution of virulence gene of Staphylococcus aureus isolated from stable nasal carries. FEMS Mircrobiol Lett. 2004;233:45-52. 10.1016/J.femsle.2004.01.032

17. Akineden O, Annemuller C, Hassan AA, LammLer C, Wolter W, Zschock M. Toxin genes and other characteristics of Staphylococcus aureus isolates from milk of cows with mastitis. Clin Diag Lab Immunol. 2001;8(5):959-964. 10. 1128/CDL1.8.5.959.964.2001

18. Idil N, Bilkay IS. Application of RAPD-PCR for determining the clonality of methicillin resistant Staphylococcus aureus isolated from different hospital. Braz Arch biol Technol. 2014;57(4):548-553. 10.1590/S1516-8913201402116

19. Yadav R, Kumar A, Singh VK, Yadar KS. Prevalence and antibiotiotyping of Staphylococcus aureus and methicillin - resistant $S$. aureus (MRSA) in domestic animals in india. J Global Antimicrob Resist. 2018;15:222-225. 10.1016/j.jgar.2018.08.001

20. Buxton A, Fraser G. Animal microbiology. Oxford: Blackwell Scientific Publications; 1977. 85-110 p. Available at http://www.iberlibro.com

21. Cowan ST. Cown and steel's manual for the identification medical bacteria. $3^{\text {th }}$ ed. Cambridge: Cambridge University Press; 1993. 52-58p. 10.1017/CB09780511527104

22. Asssfi MS, Hado HA, Abdulrahman IS. Detection of methicillinresistant Staphylococcus aureus in broiler and broilers farm workers in Duhok, Iraq by using conventional and PCR techniques. Iraqi J Vet Sci. 2020;34(1):15-22. Doi: 10.3899/ijvs.2019.125757.1145

23. Akhter J, Hossain MT, Islam MT, Siddique M, Islam MA. Isolation and identification of mircroflora from apparently healthy caged parrots of dhaka zoo of bangladesh. Bangl J Vet Med. 2010;8(1):5-10. 10.3329/bjvm.v8il.8349

24. Sarker MAH, Parvin MN, Malek MA, Hossain MT. Identification of bacterial flora isolated from apparently healthy water birds of dhaka zoo of bangladesh. Bangl J Vet Med. 2012;10(1\&2):21-26. 10.3329/bjvm.v10il-2.15642

25. Doneley RJT. Bacterial and parasitic diseases of parrots. Vet Clin Exot Anim. 2009;12(3):417-432. 10.1016/j.cvex.2009.06.009

26. Sheet OH, Grabowski NT, Klien G, Reich F, Abdulamajood ood A. Characterization of mec A gene negative Staphylococcus aureus isolated from bovine mastitis milk from northern germany. Folia Mircrobiol. 2019;64(6):845-855. 10.1007/s12223-019-00698-Z

27. Momtaz H, Dehkord FS, Rahimi E, Asgarifar A, Momeni M. Virulence genes and antimicrobial resistance profiles of Staphylococcus aureus isolated from chicken meat in Isfahan province Iran. J Appl Poult Res. 2013;22(4):913-921. 10.3382/japr.2012-00673

28. Burian M. Temporal expression of adhesion factors and activity of global regulators during establishment of Staphylococcus aureus nasal colonization. J Infect Dis. 2010;201:1414-1421. 10.1086/651619

29. Savini V. Pet- to- man travelling staphylococci: A world in progress. New York: Elsevier Inc; 2018. 112-114 p. 10.1016/C2016-0-02188-5

30. Oogai Y, Matsuo M, Komatsuzawa H. Expression of virulance factors by staphyloccus aureus grown in serum. Appl Enivron Mircrobiol. 2011;77(22):8097-8105. 101128/AEM.05316-11

31. Butterworth A, Reeves NA, Harbour D, Werrett G, Kestin SC. Molecular typing of strains of Staphylococcus aureus isolated from bone and joint lesions in lame broiler by random amplification of polymorphic DNA. Poult Scie. 2001;80(9):1339-1343. $10.1093 / \mathrm{ps} / 80.9 .1339$

32. Fitzgerald JR, Holden MTG. Genomics of natural populations of Staphyloccus aureus. Annu Rev Mircrobiol. 2016;70:459-478. $\underline{\text { 10.1146/annurev-mirco-102215-095547 }}$ 